\title{
The influence of protein nutrition in early life on growth and development of the pig
}

\section{Effects on the cellularity of muscle and subcutaneous adipose tissue}

\author{
By R. G. CAMPBELL* AND A.C. DUNKIN \\ School of Agriculture and Forestry, University of Melbourne, Parkville, \\ Victoria 3052, Australia
}

(Received 5 October 1982 - Accepted 26 May 1983)

1. The effects of feeding either high-protein (HP) or low-protein (LP) diets between 1.8 and $15 \mathrm{~kg}$ live weight (LW) and a low-energy (LE) or high-energy (HE) intake subsequently on the cellularity of muscle and adipose tissue in pigs growing to $75 \mathrm{~kg} \mathrm{LW}$ were investigated.

2. The effects of the nutritional treatments on muscle tissue were assessed from the weight and DNA content of the $m$. adductor. For adipose tissue the total DNA content and fat cell size of the subcutaneous adipose tissue contained in the left shoulder joint were determined.

3. Feeding the LP diets in early life reduced the weight and DNA content of the $m$. adductor $(P<0.01)$ and increased fat cell size $(P<0.01)$ at $15 \mathrm{~kg} \mathrm{LW}$.

4. Subsequent to $15 \mathrm{~kg}$ there was an almost linear increase in muscle DNA with increasing $L W$, and the difference between pigs from the initial protein treatments progressively diminished and was no longer apparent at $60 \mathrm{~kg}$ LW.

5. At $30 \mathrm{~kg} \mathrm{LW}$, pigs given the LP diets before $15 \mathrm{~kg} \mathrm{LW}$ contained less DNA in the subcutaneous adipose tissue from the shoulder joint $(P<0.01)$ and had larger fat cells $(P<0.05)$ than pigs given the HP diets initially. However, adipose DNA and fat cell size increased with increasing LW and the differences resulting from the initial protein treatments progressively diminished. On the LE and HE treatments subsequent to $15 \mathrm{~kg}$ these differences were no longer evident at 45 and $60 \mathrm{~kg}$ respectively.

6. Pigs given the HE intake subsequent to $15 \mathrm{~kg}$, contained less DNA in muscle tissue $(P<0.05)$ at 60 and $75 \mathrm{~kg} \mathrm{LW}$ and had larger fat cells $(P<0.05)$ at 45,60 and $75 \mathrm{~kg} \mathrm{LW}$, than pigs on the LE treatment.

Previous research at this centre (Campbell \& Dunkin, 1980) indicated that protein deprivation over the live weight (LW) range $1.8-6.5 \mathrm{~kg}$ adversely affected the hyperplastic development of porcine muscle and subcutaneous adipose tissue and that these effects were still evident at $45 \mathrm{~kg} \mathrm{LW}$. The results of Gilbreath \& Trout (1973) also suggest that protein restriction in early life reduces muscle DNA. However, for the pig there is little information on the extent to which cellular hyperplasia contributes to the post-natal development of muscle or adipose tissue. Thus, it is difficult to assess whether the adverse effects of protein deprivation in early life on the cellular development of either tissue are likely to be permanent or only transitory.

The experiment reported by Campbell \& Dunkin (1983) provided the opportunity to investigate the effects of protein nutrition between 1.8 and $15 \mathrm{~kg} \mathrm{LW}$ and subsequent energy intake on the cellularity of muscle and subcutaneous adipose tissue of pigs grown to $75 \mathrm{~kg}$ LW. Because pigs were killed at LW intervals of $15 \mathrm{~kg}$ between 15 and $75 \mathrm{~kg}$, the experiment also provided information on the progressive changes in the cellularity of both tissues with increase in LW.

\section{EXPERIMENTAL}

General

Forty-two entire male piglets (Large White) were removed from their dams between 24 and $36 \mathrm{~h}$ after birth and as their individual $\mathrm{LW}$ reached $1.8 \mathrm{~kg}$ were randomly allocated to either

\footnotetext{
* Present address: Animal Research Institute, Werribee, Victoria 3030, Australia
} 
Table 1. Effects of dietary protein content between 1.8 and $15 \mathrm{~kg}$ live weight $(L W)$ on cellularity of muscle and muscle and subcutaneous adipose tissue in pigs at $15 \mathrm{~kg} \mathrm{LW}$

\begin{tabular}{|c|c|c|c|c|}
\hline Dietary protein level $\dagger \ldots$ & $\begin{array}{l}\text { High } \\
\text { (HP) }\end{array}$ & $\begin{array}{l}\text { Low } \\
\text { (LP) }\end{array}$ & SEM & $\begin{array}{l}\text { Statistical } \\
\text { significance of } \\
\text { difference } \\
\text { HP v. LP }\end{array}$ \\
\hline \multicolumn{5}{|l|}{ Adductor muscle } \\
\hline Wt $(\mathrm{g})$ & 59.7 & $50 \cdot 3$ & 0.78 & ** \\
\hline DNA (mg) & $36 \cdot 3$ & $27 \cdot 2$ & 0.60 & ** \\
\hline \multicolumn{5}{|l|}{ Subcutaneous adipose tissue } \\
\hline Average fat cell diameter $(\mu \mathrm{m})$ & $34 \cdot 1$ & $49 \cdot 1$ & 1.8 & ** \\
\hline
\end{tabular}

** $P<0.01 . \quad \dagger$ For details, see Campbell \& Dunkin (1983).

Table 2. Effect of dietary protein content between $1 \cdot 8$ and $15 \mathrm{~kg}$ live weight $(\mathrm{LW})$ and subsequent $L W$ on weight of the $\mathrm{m}$. adductor in pigs at $30,45,60$ and $75 \mathrm{~kg} L W$

(Values averaged for low-energy and high-energy treatments subsequent to $15 \mathrm{~kg} \mathrm{LW}$ )

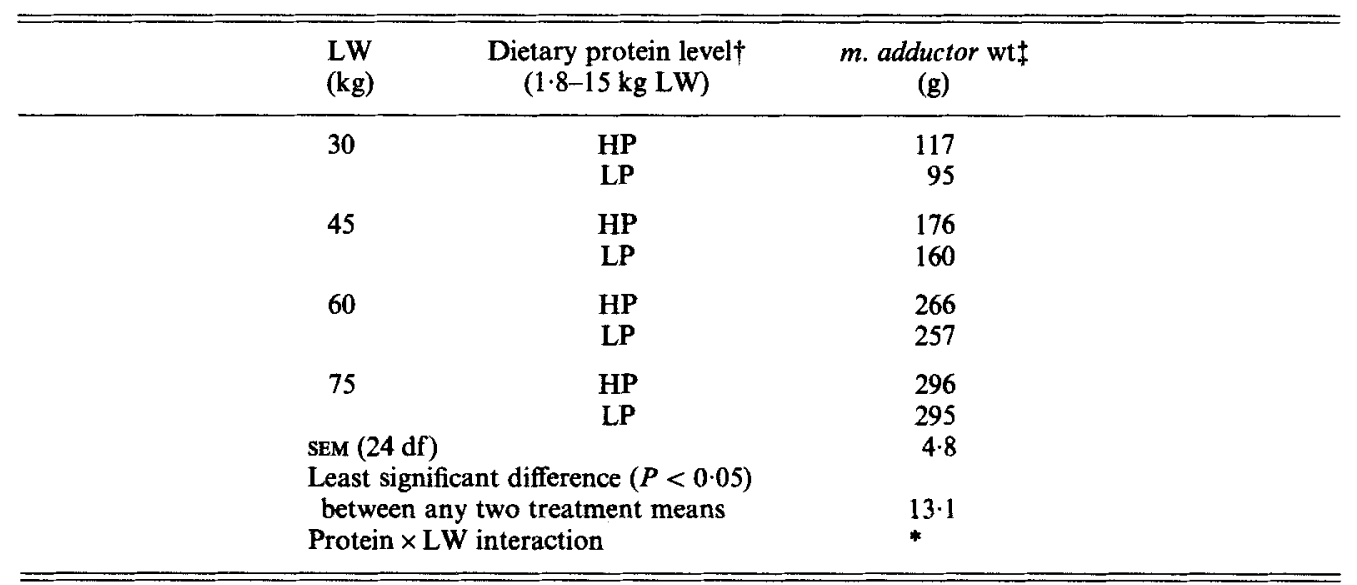

HP, high-protein; LP, low-protein.

* $P<0.05$.

$\dagger$ For details, see Campbell \& Dunkin (1983).

$\ddagger$ Four pigs per treatment mean.

a low-protein (LP) or high-protein (HP) treatment to $15 \mathrm{~kg} \mathrm{LW}$. At the latter weight three pigs from each treatment were killed. The remaining animals were allocated equally to a low-energy (LE) or a high-energy (HE) treatment to $75 \mathrm{~kg} \mathrm{LW}$. From each of the four treatment combinations, subsequent to $15 \mathrm{~kg} \mathrm{LW}$, two pigs chosen at random were killed at each of four $\mathrm{LW}(30,45,60,75 \mathrm{~kg})$. Two pigs from each of the pre-15 kg LW treatment groups died. Consequently, only sixteen pigs were allocated to the LE and HE treatments subsequent to $15 \mathrm{~kg}$. Subsequent to $15 \mathrm{~kg} \mathrm{LW}$ the results were analysed as a $2 \times 2 \times 4$ factorial design with two replicates per treatment. The respective factors were, level of dietary protein before $15 \mathrm{~kg} \mathrm{LW}$ (HP and LP), level of energy intake after $15 \mathrm{~kg} \mathrm{LW}$ (LE and $\mathrm{HE})$ and $\mathrm{LW}$ at slaughter $(30,45,60$ and $75 \mathrm{~kg})$. Details of the diets and management procedures have been described previously (Campbell \& Dunkin, 1983). 
Table 3. Effects of dietary protein content between 1.8 and $15 \mathrm{~kg}$ live weight $(L W)$, subsequent energy intake and $L W$ on the DNA content of the $\mathrm{m}$. adductor of pigs at $30,45,60$ and $75 \mathrm{~kg}$ LW (two pigs per treatment)

\begin{tabular}{|c|c|c|c|c|c|c|}
\hline LW $(\mathrm{kg}) \ldots$ & $\begin{array}{c}\text { Dietary protein level } \dagger \\
1 \cdot 8-15\end{array}$ & $\underset{15-75}{\text { Energy intake } \dagger}$ & 30 & 45 & 60 & 75 \\
\hline & HP & $\begin{array}{l}\text { LE } \\
\text { HE }\end{array}$ & $\begin{array}{l}51 \cdot 0 \\
49 \cdot 0\end{array}$ & $\begin{array}{l}69 \cdot 4 \\
64 \cdot 5\end{array}$ & $\begin{array}{l}84 \cdot 9 \\
81 \cdot 3\end{array}$ & $\begin{array}{l}102 \\
97 \cdot 7\end{array}$ \\
\hline & LP & $\begin{array}{l}\text { LE } \\
\text { HE }\end{array}$ & $\begin{array}{l}44 \cdot 2 \\
40 \cdot 0\end{array}$ & $\begin{array}{l}67 \cdot 3 \\
59 \cdot 2\end{array}$ & $\begin{array}{l}83 \cdot 5 \\
81 \cdot 6\end{array}$ & $\begin{array}{l}105 \\
98 \cdot 4\end{array}$ \\
\hline \multicolumn{3}{|c|}{$\begin{array}{l}\text { Protein } \times \text { energy interaction } \\
\text { SEM }(16 \mathrm{df}): 1 \cdot 4 \\
\text { Least significant difference }(P<0 \cdot 05) \\
\text { between any two treatment means: } 4 \text {. }\end{array}$} & $*$ & * & NS & NS \\
\hline
\end{tabular}

$* P<0.05 ;$ NS, not significant.

HP, high-protein; LP, low-protein; LE, low-energy; HE, high-energy.

$\dagger$ For details, see Campbell \& Dunkin (1983).

\section{Post-slaughter procedures}

Immediately after slaughter the $m$. adductor was removed from the right hind leg, weighed and stored at $-30^{\circ}$ for subsequent DNA analysis.

A section of subcutaneous adipose tissue, measuring approximately $10 \times 20 \mathrm{~mm}$, was also removed from directly above the first thoracic vertebra and divided into two equal portions. One portion was prepared immediately for fat cell size determinations. The other was stored at $-30^{\circ}$ for subsequent DNA analysis. The left shoulder joint of pigs killed at $30,45,60$ and $75 \mathrm{~kg} \mathrm{LW}$ was removed by two transverse cuts passing between the atlas and occipital process and between the second and third thoracic vertebrae respectively. The subcutaneous adipose tissue contained in the shoulder joint was dissected out and weighed. The total DNA content of the dissected tissue was calculated as: weight of dissected tissue $(\mathrm{g}) \times$ DNA concentration of tissue $(\mathrm{mg} / \mathrm{g})$.

\section{Measurement of tissue cellularity}

The DNA content of muscle and adipose tissue was determined using the method of Martin $\&$ Donohue (1972). The analysis of adipose tissue was preceded by extraction of lipid from the samples by shaking in cold chloroform - methanol $(2: 1, \mathrm{v} / \mathrm{v})$ for 5-6 min. Average fat cell size was determined on duplicate samples by measuring the maximum diameters of 300 consecutive adipocytes using the collagenase technique of Smith et al. (1972).

\section{RESULTS \\ $1 \cdot 8-15 \mathrm{~kg} \mathrm{LW}$}

At $15 \mathrm{~kg} \mathrm{LW}$ the $m$. adductor from pigs on the LP treatment was lighter $(P<0.01)$ and contained less DNA $(P<0.01)$ than that from pigs on the HP treatment. Pigs given the LP diets also contained larger fat cells $(P<0 \cdot 01)$ than those given the HP diets (Table 1).

There was a significant $(P<0.05)$ interaction between the effects of protein nutrition before $15 \mathrm{~kg} \mathrm{LW}$ and subsequent LW for the weight of the $m$. adductor (Table 2). Muscle weight increased in a linear fashion with increasing LW but the difference between the two initial protein groups declined progressively as LW increased.

For muscle DNA there was a significant interaction $(P<0.05)$ between the effects of 


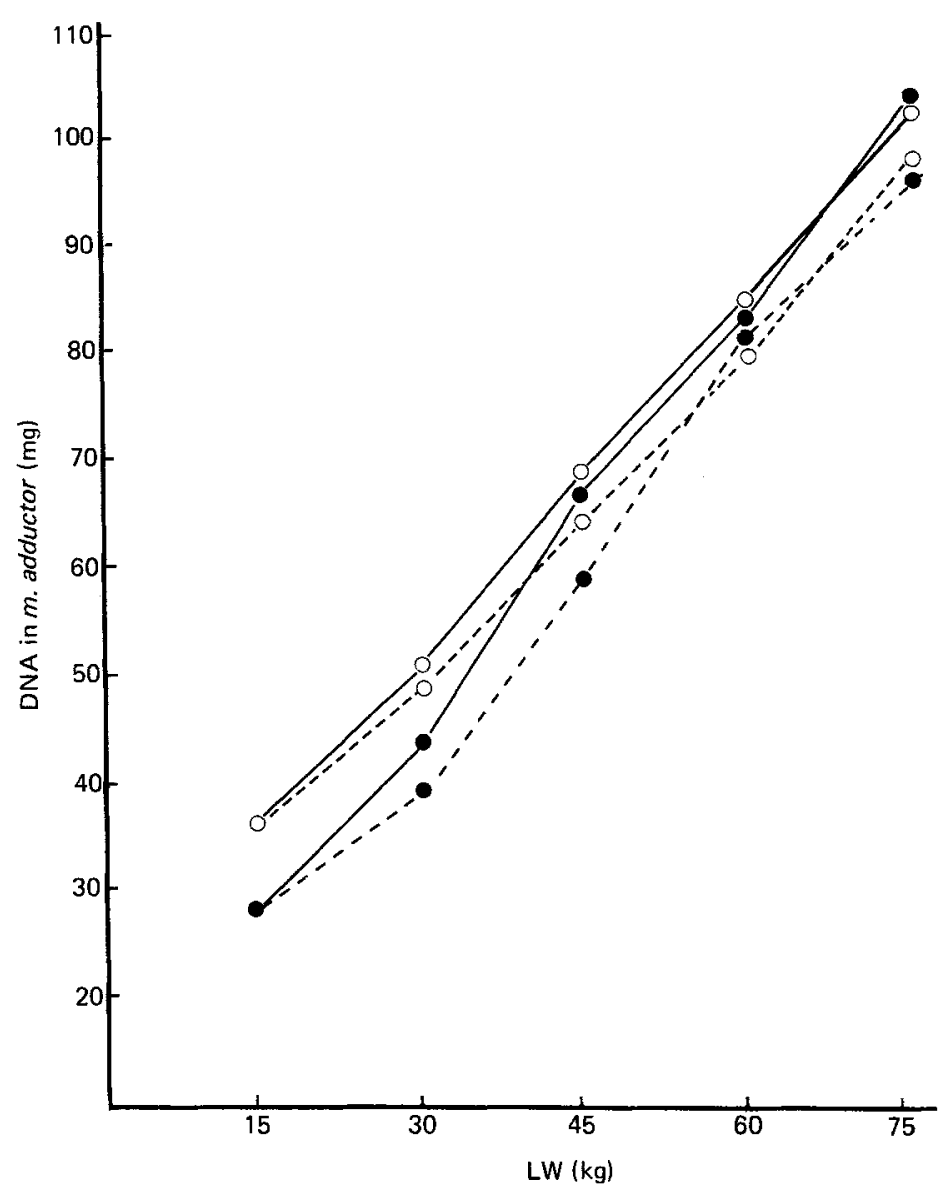

Fig. 1. Effects of feeding pigs a high-protein $(O)$ or a low-protein $(\Theta)$ diet from 1.8 to $15 \mathrm{~kg}$ live weight (LW) and a low-energy (---) or high-energy ( $\longrightarrow$ intake subsequent to $15 \mathrm{~kg} \mathrm{LW}$ on the DNA content of the m. adductor. For details of treatments, see Campbell \& Dunkin (1983).

protein nutrition to $15 \mathrm{~kg}$, subsequent energy intake and subsequent $\mathrm{LW}$. The results are presented in Table 3 and shown diagrammatically in Fig. 1. Muscle DNA increased in a linear fashion with increasing LW and was lower $(P<0.05)$ at $75 \mathrm{~kg} \mathrm{LW}$ in pigs given the $\mathrm{HE}$ intake subsequent to $15 \mathrm{~kg}$ relative to those given the LE after $15 \mathrm{~kg}$. However, within the LE treatment, pigs previously given the LP diets contained less muscle DNA at $30 \mathrm{~kg}$ than those previously given the HP diets but this difference was no longer evident at $45 \mathrm{~kg}$. On the HE treatment, pigs previously given the LP diets contained less muscle DNA to $45 \mathrm{~kg}$ than pigs on all other treatments. Differences due to the initial protein treatments progressively diminished as LW increased and were no longer significant at 60 or $75 \mathrm{~kg} \mathrm{LW}$.

There was a significant interaction $(P<0.05)$ between the effects of protein nutrition before $15 \mathrm{~kg} \mathrm{LW}$ and subsequent LW both for the DNA content of subcutaneous adipose tissue and fat cell size (Table 4). Pigs given the LP diets contained less DNA at LW of 30 and $45 \mathrm{~kg}$ and had larger fat cells at 30,45 and $60 \mathrm{~kg}$ than pigs given the HP diets before $15 \mathrm{~kg}$. However, these differences gradually diminished and, at $75 \mathrm{~kg}$, were no longer 
Table 4. Effects of dietary protein content between 1.8 and $15 \mathrm{~kg}$ live weight $(L W)$ and subsequent $L W$ on the cellularity of subcutaneous adipose tissue in pigs at 30,45, 60 and $75 \mathrm{~kg} \mathrm{LW}$

(Values averaged for low-energy and high-energy treatments subsequent to $15 \mathrm{~kg} \mathrm{LW}$ )

\begin{tabular}{|c|c|c|c|}
\hline \multirow[b]{2}{*}{$\begin{array}{l}\mathrm{LW} \\
(\mathrm{kg})\end{array}$} & \multirow[b]{2}{*}{ Dietary protein $\dagger$} & \multicolumn{2}{|c|}{ Subcutaneous fat in shoulder joint $\ddagger$} \\
\hline & & $\begin{array}{l}\text { Total DNA } \\
\quad(\mathrm{mg})\end{array}$ & $\begin{array}{l}\text { Average fat cell diameter } \\
(\mu \mathrm{m})\end{array}$ \\
\hline 30 & $\begin{array}{l}\text { HP } \\
\text { LP }\end{array}$ & $\begin{array}{l}201 \\
170\end{array}$ & $\begin{array}{l}53 \cdot 3 \\
62 \cdot 5\end{array}$ \\
\hline 45 & $\begin{array}{l}\text { HP } \\
\text { LP }\end{array}$ & $\begin{array}{l}243 \\
219\end{array}$ & $\begin{array}{l}64 \cdot 5 \\
68 \cdot 0\end{array}$ \\
\hline 60 & $\begin{array}{l}\text { HP } \\
\text { LP }\end{array}$ & $\begin{array}{l}332 \\
321\end{array}$ & $\begin{array}{l}71 \cdot 6 \\
75 \cdot 4\end{array}$ \\
\hline 75 & $\begin{array}{l}\text { HP } \\
\text { LP }\end{array}$ & $\begin{array}{l}365 \\
376\end{array}$ & $\begin{array}{l}83 \cdot 7 \\
85 \cdot 6\end{array}$ \\
\hline \multicolumn{2}{|c|}{$\begin{array}{l}\text { SEM }(24 \mathrm{df}) \\
\text { Least significant difference } \\
(P<0 \cdot 05) \text { between any two } \\
\text { means }\end{array}$} & $\begin{array}{l}10 \cdot 3 \\
21 \cdot 0\end{array}$ & $\begin{array}{l}1.2 \\
3.4\end{array}$ \\
\hline
\end{tabular}

HP, high-protein; LP, low-protein.

$\dagger$ For details, see Campbell \& Dunkin (1983).

$\ddagger$ Four pigs per treatment mean.

significant. The changes between 30 and $75 \mathrm{~kg} \mathrm{LW}$ for adipose DNA and for fat cell size between 15 and $75 \mathrm{~kg} \mathrm{LW}$ are shown diagrammatically in Figs. 2 and 3 respectively.

Raising energy intake subsequent to $15 \mathrm{~kg}$ increased average fat cell size $(P<0.05)$. The means for average fat cell diameter $(\mu \mathrm{m})$, pooled for $\mathrm{LW}$, were 73.5 and 66.2 for pigs on the HE and LE treatments respectively.

\section{DISCUSSION}

The results showed that the cellularity of muscle and subcutaneous adipose tissue was influenced by $\mathrm{LW}$, protein nutrition before $15 \mathrm{~kg} \mathrm{LW}$ and by subsequent energy intake. The results for DNA suggest that protein deprivation before $15 \mathrm{~kg} \mathrm{LW}$ retarded the hyperplastic development of both tissues. Taken in conjunction with the results for body fat content (Campbell \& Dunkin, 1983) the results indicate that at $15 \mathrm{~kg} \mathrm{LW}$ the fattest pigs contained the least number of adipocytes and that the larger fat cells exhibited at 15,30 and $45 \mathrm{~kg}$ by pigs previously given the LP diets were the net effect of these animals having to accommodate more fat into fewer cells than those given the HP diets before $15 \mathrm{~kg}$. The same effect has been observed in a previous experiment at this centre (Campbell \& Dunkin, 1980) in which pigs given a LP diet from 1.8 to $6.5 \mathrm{~kg} \mathrm{LW}$ contained fewer but larger fat cells at both 6.5 and $45 \mathrm{~kg} \mathrm{LW}$ than pigs given a HP diet before $6.5 \mathrm{~kg} \mathrm{LW}$. The results of both experiments demonstrate the elasticity in size of porcine adipocytes and suggest that fat cell number has little effect on the animal's propensity for fat development.

On the other hand, the lower level of muscle DNA exhibited at $15 \mathrm{~kg} \mathrm{LW}$ by the protein-deprived pigs may have been the major factor responsible for these animals exhibiting a slower rate of protein deposition and $\mathrm{LW}$ gain on the $\mathrm{HE}$ treatment subsequent to $15 \mathrm{~kg} \mathrm{LW}$ than pigs previously given the HP diets (Campbell \& Dunkin, 1983). A similar 


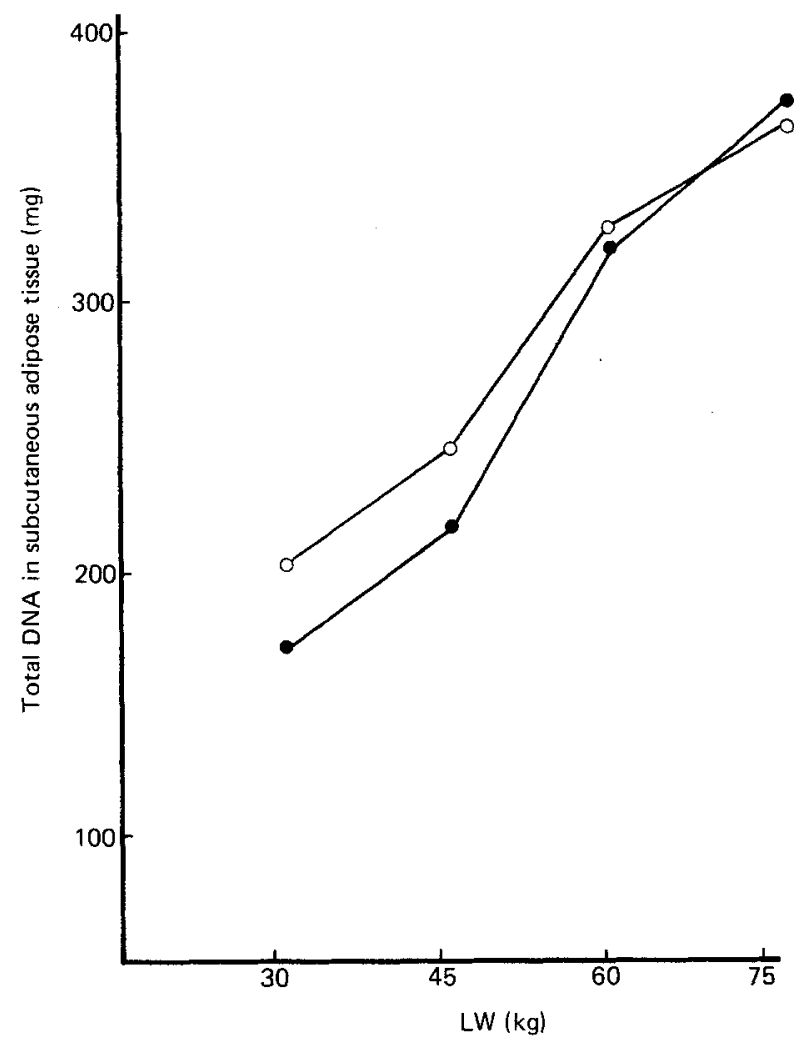

Fig. 2. Effects of feeding pigs a high-protein $(O)$ or a low-protein $(O)$ diet from 1.8 to $15 \mathrm{~kg}$ live weight (LW) on the DNA content of subcutaneous adipose tissue in the left shoulder joint subsequent to $15 \mathrm{~kg} \mathrm{LW}$. For details of diets, see Campbell \& Dunkin (1983).

relationship between muscle DNA and subsequent protein deposition has been reported to occur in poultry (Moss, 1968). In a review of muscle development in meat animals, Allen et al. (1979) also concluded that the accretion of DNA in muscle tissue paralleled and possibly preceded protein deposition. The latter contention is further supported by the results of the present experiment, since the rapid increase in the rate of muscle DNA accretion exhibited between 45 and $60 \mathrm{~kg}$ by the formerly protein-deprived pigs on the HE treatment was associated with a rapid increase in the rates of protein deposition and $\mathrm{LW}$ gain (Campbell \& Dunkin, 1983).

The results subsequent to $15 \mathrm{~kg}$ showed that the effects of protein deprivation in early life on the DNA content of muscle and subcutaneous adipose tissue were transitory, their persistence being dependent on energy intake in the later period. Furthermore, the almost linear increase in DNA in muscle and subcutaneous adipose tissue with increasing LW indicates that cellular hyperplasia contributes to the development of both tissues to at least $75 \mathrm{~kg} \mathrm{LW}$. It was also evident from the lower level of muscle DNA exhibited at 60 and $75 \mathrm{~kg} \mathrm{LW}$ by pigs on the HE relative to those on the LE treatment that the vulnerability of muscle hyperplasia to nutritional stress is not limited to the early post-natal period; although this effect may have been due to the HE diet having a lower protein: energy value $(11.1 \mathrm{~g} / \mathrm{MJ}$ digestible energy (DE)) than the LE diet (14.4 g/MJ DE), rather than effect of energy intake per se. The combination of giving the LP diets up to $15 \mathrm{~kg} \mathrm{LW}$ and the 


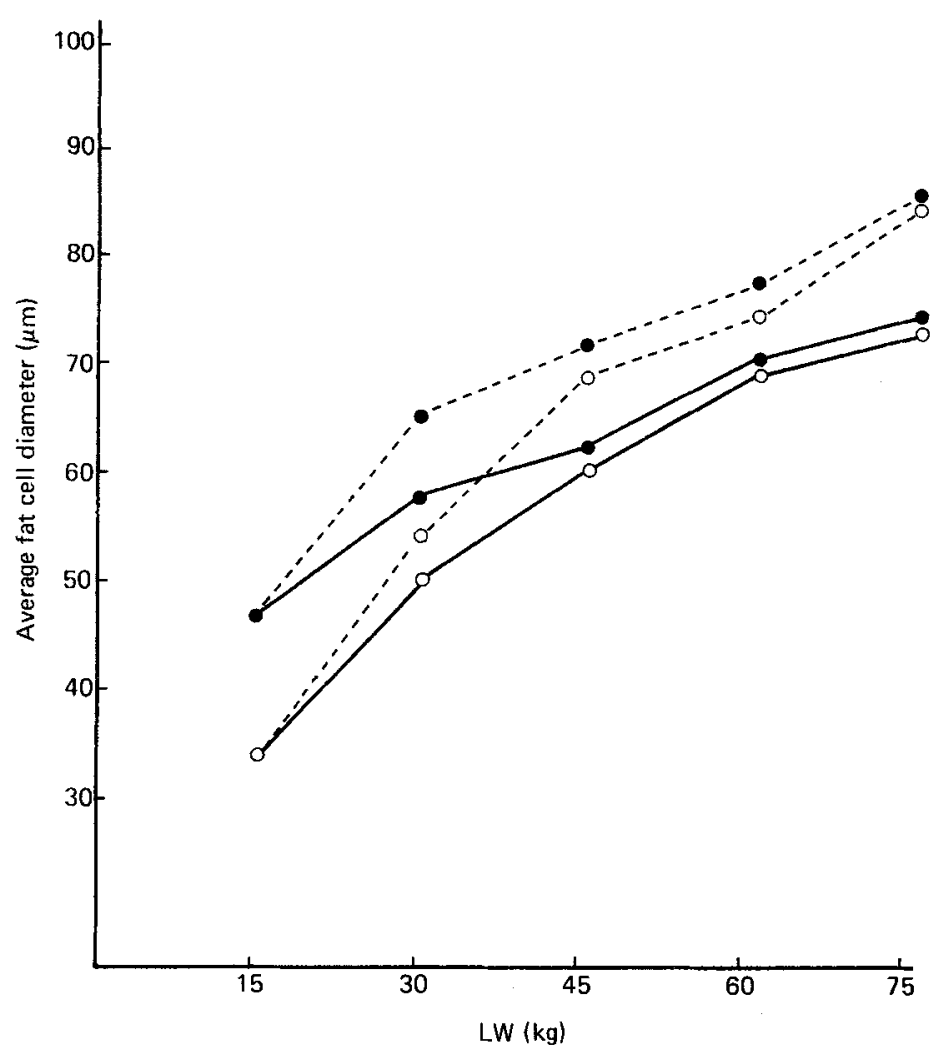

Fig. 3. Effects of feeding pigs a high-protein $(O)$ or low-protein $(O)$ diet from 1.8 to $15 \mathrm{~kg}$ live weight (LW) and a low energy (---) or high-energy (- - intake subsequent to $15 \mathrm{~kg} \mathrm{LW}$ on fat cell diameter of subcutaneous adipose tissue between 15 and $75 \mathrm{~kg} \mathrm{LW}$. For details of treatments, see Campbell \& Dunkin (1983).

diet with lower protein:energy value immediately after may have also been responsible for the very low level of muscle DNA exhibited at $30 \mathrm{~kg}$ by pigs on the LP-HE treatment. These results do not support the suggestion of Robinson (1969) and Lee et al. $(1973 a, b)$ that the post-natal development of porcine muscle and adipose tissue is characterized by cellular hypertrophy. However, our values for subcutaneous adipose tissue are in agreement with those of Hood \& Allen (1977), Wood et al. (1978) and Kirtland \& Gurr (1980).

The almost linear relationships between LW, and muscle and adipose DNA and fat cell size observed in the present experiment suggest that the effects of nutrition on tissue cellularity needs to be assessed in animals of constant weight. A similar conclusion was arrived at by Lee $e t a l$. $(1973 a, b)$ who reported that nutrition in early life appeared to have a marked effect on the cellularity of adipose tissue in pigs compared at constant age but that most of the differences disappeared when animals were compared at constant weight. Nevertheless, in the majority of experiments to study the influence of early nutrition on the cellularity of muscle (eg. Robinson, 1969; Gilbreath \& Trout, 1973; Martin et al. 1974; Lodge et al. 1977) and adipose (eg. Martin et al. 1974) tissue, between-treatment comparisons have been made at constant age but at widely different body-weights. Thus, the conclusions drawn from these values may be erroneous and require critical re-evaluation.

Similarly, research with rats has suggested that pre-weaning feed restriction reduces fat cell number and that this, in turn, may prevent obesity in the adult (Hirsch \& Han, 1969; 
Hirsch \& Knittle, 1970; Oscai et al. 1972, 1974; Bertrand \& Masoro, 1977). However, since invariably these comparisons have been made between animals of the same age but of widely different body-weights both at infancy and adulthood, it is probable that these conclusions also may be misleading.

In conclusion, the results indicate that protein restriction during early development reduces DNA in both muscle and subcutaneous adipose tissue. These effects appear transient, their persistence being dependent on subsequent nutrition. However, although the reduction of adipose DNA appears to have little effect on performance or body composition, the results for growth performance (Campbell \& Dunkin, 1983) suggest that the resultant decrease in muscle DNA limits the rate of protein accretion and consequent LW gain during subsequent development, and that these effects persist until muscle DNA is rehabilitated.

The authors wish to thank Mrs S. Oldfield and Mr W. Chapman for their expert technical assistance and Mr R. Jardine for the statistical analysis of the results. The work was supported by a grant from the Australian Pig Industry Research Committee.

\section{REFERENCES}

Allen, R. E., Merkel, R. A. \& Young, R. B. (1979). Journal of Animal Science 49, 115-127.

Bertrand, H. A. \& Masoro, E. J. (1977). Nature 266, 62-63.

Campbell, R. G. \& Dunkin, A. C. (1980). Proceedings of the Australian Society of Animal Production 13, $131-133$.

Campbell, R. G. \& Dunkin, A. C. (1983). British Journal of Nutrition 50, 605-617.

Gilbreath, R. L. \& Trout, J. R. (1973). Journal of Nutrition 203, 1637-1645.

Hirsch, J. \& Han, P. W. (1969). Journal of Lipid Research 10, 77-82.

Hirsch, J. \& Knittle, J. L. (1970). Federation Proceedings 29, 1516-1521.

Hood, R. L. \& Allen, C. E. (1977). Journal of Lipid Research 18, $275-284$.

Kirtland, J. \& Gurr, M. I. (1980). Journal of Agricultural Science, Cambridge 95, 325-331.

Lee, Y. B., Kauffman, R. G. \& Grummer, R. H. (1973a). Journal of Animal Science 37, 1312-1318.

Lee, Y. B., Kauffman, R. G. \& Grummer, R. H. (1973 b). Journal of Animal Science 37, 1319-1325.

Lodge, G. A., Sarker, N. K. \& Friend, B. W. (1977). Journal of Animal Science 45, 1346-1352.

Martin, R. F. \& Donohue, D. C. (1972). Analytical Biochemistry 47, 562-574.

Martin, R. J., Ezekwe, M., Herbein, J. H., Sherritt, G. W., Gobble, J. L. \& Ziegler, J. H. (1974). Journal of Animal Science 39, 521-526.

Moss, F. P. (1968). American Journal of Anatomy 122, 555-564.

Oscai, L. B., Bibirak, S. P., Dubach, F. B., McGarr, J. A. \& Spirakis, C. N. (1974). American Journal of Physiology 227, 901-904.

Oscai, L. B., Spirakis, C. N. \& Wolff, C. A. (1972). Journal of Lipid Research 13, 588-592.

Robinson, D. W. (1969). Growth 33, 231-240.

Smith, U., Sjostrom, L. \& Bjorntorp, P. (1972). Journal of Lipid Research 13, 822-824.

Wood, J. P., Enser, M. B. \& Restall, D. J. (1978). Animal Production 27, 1-10. 